The Poetry of Nizami Ganjavi 
This page intentionally left blank 


\section{The Poetry of Nizami Ganjavi: Knowledge, Love, and Rhetoric}

Edited by Kamran Talattof and Jerome W. Clinton 


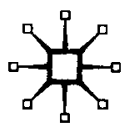

Copyright $\odot$ Kamran Talattof and Jerome W. Clinton, 2000.

Softcover reprint of the hardcover 1st edition 2000 978-0-312-22810-1

All rights reserved. No part of this book may be used or reproduced in any manner whatsoever without written permission except in the case of brief quotations embodied in critical articles or reviews.

First published 2000 by

PALGRAVETM

175 Fifth Avenue, New York, N.Y. 10010 and

Houndmills, Basingstoke, Hampshire, England RG21 6XS.

Companies and representatives throughout the world.

PALGRAVETM is the new global publishing imprint of St. Martin's Press LLC Scholarly and Reference Division and Palgrave Publishers Ltd (formerly Macmillan Press Ltd).

ISBN 978-1-349-62615-1

ISBN 978-1-137-09836-8 (eBook)

DOI 10.1007/978-1-137-09836-8

A catalogue record for this book is available from the British Library.

Library of Congress Cataloging-in-Publication Data

The poetry of Nizami Ganjavi: knowledge, love, and rhetoric / edited by Kamran Talattof and Jerome $W$. Clinton.

p. $\mathrm{cm}$.

Consists of the majority of the papers presented at a

commemoration symposium for K. Allin Luther at

Princeton University on February 21-22, 1998.

Includes bibliographical references and index.

1. Niơamå Ganjavå, 1140 or 41-1202 or 3-Criticism and interpretation-Congresses. I. Talattof, Kamran. II. Clinton, Jerome W. III. Luther, K. Allin, d. 1997.

PK6501.Z928 2000

$897^{\prime} .5511-\mathrm{dc} 21$

99-056710

CIP

First edition: December 2000

10987654321 
In Memory of K. Allin Luther 
This page intentionally left blank 


\section{Contents}

Preface

A Note on Transliteration

Introduction: Nizami Ganjavi and His Poetry

Chapter 1 A Comparison of Nizami's Layli and Majnun and Shakespeare's Romeo and Juliet

Jerome W. Clinton

Chapter 2 Layla Grows Up: Nizami's Layla and Majnun "in the Turkish Manner"

Mehmed Kalpakli and Walter G. Andrews

Chapter 3 Nizami's Unlikely Heroines: A Study of the

Characterizations of Women in Classical

Persian Literature

Kamran Talattof

Chapter 4 Majnun's Image as a Serpent

Asghar Abu Gohrab

Chapter 5 The Historian and the Poet: Rāvandī, Nizami, and the Rhetoric of History

Julie Scott Meisami

Chapter 6 Occult Sciences in The Iskandarnameh of Nizami

J. Christoph Bürgel

Chapter 7 Nizami's Poetry Versus Scientific Knowledge:

The Case of the Pomegranate

Christine van Ruymbeke

Chapter 8 Music in Khusraw Va Shirin 
viii Contents

Chapter 9 The Story of the Ascension (Mi'raj) in Nizami's Work

C.-H. De Fouchécour, Translated by

Kamran Talattof and Arjang Talattof

Chapter 10 International Recognition of Nizami's Work:

A Bibliography

Kamran Talattof

Index

205 


\section{Preface}

The work of Nizami Ganjavi, one of the great Persian poets, has achieved enduring significance. A year does not go by without the publication of new books and articles about his poetry, and although he belongs to the classical period of Persian poetry, the interpretation of his work has fueled a cultural debate in Iran in recent years. A reexamination of Nizami's work will not only shed light on the complex aspects of his poetry, but will also contribute to the ongoing cultural debate and the question of interpretation.

For the editors and some contributors, however, Nizami has additional personal significance. Our esteemed professor, K. Allin Luther, taught the poetry of Nizami for more than a decade at the University of Michigan, finding in it a source of strength and fortitude as he struggled with terminal illness. He died in 1997. To commemorate the life and work of K. Allin Luther, we organized a symposium on the poetry of Nizami Ganjavi on February 21-22, 1998, at Princeton University. This volume includes the majority of papers presented at that symposium, as well as two added later.

A well-known scholar of Iranian history and Persian studies, Luther received a B.A. from the University of Florida in 1955, a master's degree from Princeton University in 1959, and a Ph. D. from Princeton University in 1964. He studied at Hamburg University with Professor Berthold Spuler and, as part of his graduate studies, conducted research in Iran and Turkey. He taught at Portland State University and then joined the faculty at the University of Michigan, where he taught until 1995. He wrote about the history of the Saljuqs, Ilkhanids, and Atabaks of Azerbayjan.

Serious academicians often develop great respect over time for the subjects of their studies. They become closely associated with their topics and their lives become enmeshed in their research. Luther was no exception. He devoted himself to Iranian history, Persian literature, and his students in Iranian studies. He went beyond his official teaching responsibilities to organize the Nizami reading group in Ann Arbor and continued to lead it long after his retirement. For those who knew Allin Luther, this volume will have particular significance. Moreover, we hope that this book encourages more study of the works of Nizami Ganjavi. 


\section{A Note on Transliteration}

The contributors to this volume have employed different systems of transliteration. In an attempt to be consistent, we have generally adjusted these to conform to the transliteration system of the Library of Congress. We have not, however, employed this system with complete fidelity, so the reader will find both Iskandar Nama and Iskandernameh. We have also left unchanged the transliteration of original poetry and excerpts in order to respect the authors' choices. 